\title{
An Analysis of Student Teacher Relations and its Effects on Child's Educational Outcome
}

\author{
Asad Ullah*, Fawad Hussain and Mussawar Shah \\ Department of Rural Sociology, University of Agriculture, Peshawar-Pakistan
}

Submission: March 08, 2017; Published: September 27, 2017

*Corresponding author: Asad Ullah, Department of Rural Sociology, University of Agriculture Peshawar Pakistan, Tel: +92-91-9218438;

Tel No: +92-3005824733; Email: asadpsh@aup.edu.pk

\begin{abstract}
The objective of this research paper is to find out the relationship between student teacher relations and child's educational outcomes. A total of 331 students were selected from a population of 2984 through systematic random sampling technique from seven different government and private schools of the district Peshawar and were interviewed through a well-designed interview schedule. Association of variables was worked out through chi-square test. Association of educational outcomes was found highly significant with positive relationship with teachers, teachers regulated student's behavior, feeling no fear or shy in asking question from teacher, motivation from teachers to take interest in school/education, teaching in conducive educational environment and with teacher helped their students in structuring their daily experiences.

Ensuring effective utilization of capabilities from both teacher's and student's side for their productive outputs. This can be achieved by initiating and replicating teacher training programs that ensure improving best educational and psychological skill to teachers so that they can educate students in best efficient way. In addition, strengthening teacher student relationship by reducing reluctance in both groups towards each other and developing strong affiliations among teachers and students based on care and sympathy were some of the recommendations in the light of the study.
\end{abstract}

\section{Introduction}

A strong and positive relationship of student and teacher provide the foundation for the healthy development of all children in their school. A positive relationship between student and teacher reduces the risk of educational failure and conflict between the teacher and student Wetzel \& Asher [1]. The student teacher relation may also foster the socio emotional development of children. Positive student teacher relationship helped the students to develop the sense that they are safe and secure in their school environment and also shaped their social and academic development. Student teacher relation relationship is also important for those children who are facing early academic and behavioral problems.

It is also found that supportive student teacher relationship have played an important role for the diminishing of aggressive behavior among the children. The need for a positive student teacher do not decrease as children mature but student teacher relationships may be more prominent when students goes from elementary to middle school. Those students who have a conflictual relationship with their teachers, they are not accepted by the rest of the students[2].
Pianta [3] has demonstrated that educational outcomes are directly and indirectly influenced by the student teacher relationship. She proposed that emotionally and academically healthy children can be produced if a positive relationship is developed between early elementary teachers and their students and if such type of relationship is established and sustained it will support and shape a student's development throughout the early school years and later on. Some other researchers also agreed with Pianta and found that the quality of the student teacher relationship helps to foster not only achievement but mediating factors (i.e., motivational and learning related Processes) that are important to academic functioning.

Medina \& Luna [4] and Hughes [5] have found that the quality of the student teacher relationship is associated with academic performance, solving problem, regulation of the emotions, and emotional understanding. A positive relationship with the kindergarten teacher was associated with more positive outcomes such as good behavior and higher levels of competence. In contrast negative and conflictual relationship with a kindergarten teacher is related with bad educational outcomes also including behavioral problems and low competence level. 


\section{Global Journal of Archaeology \& Anthropology}

\section{Material and Methods}

The present study was carried out at district Peshawar to find out the relation between child rearing practices and educational outcomes. More specifically the data was collected from seven different Government and private schools of district Peshawar. A sample of 331 was selected from a population of 2984 through stratified random sampling as per sekaran (2003) method. The data was collected through interview schedule and analysis of the data was carried out through SPSS software. For frequency distribution and percentage of background, independent and dependent variables Uni-variate analysis was carried out, percentage of each data classes was calculated using following formula (Sekaran 2003).

Percentage of a class $=\mathrm{f} / \mathrm{N} * 100$ Where $\mathrm{f}=$ frequency of data class and $\mathrm{N}=$ numbers of observations in the data set.
In order to observe association between dependent and independent variables, Bi-variate was analysis was carried out. For testing the association between two variables, chi-square test was applied as explained below.

$$
\chi^{2}=\sum_{i=1}^{r} \sum_{j=1}^{c} \frac{\left(O_{i j}-e_{i j}\right)^{2}}{e_{i j}}
$$

$\mathrm{X}^{2}=$ Chi-square for categorical variables

fij $=$ The observe frequency in $\mathrm{i}$ row and $\mathrm{j}$ column fij $=$ The expected frequency of $i$ and $j$

The degree of freedom was calculated as $\mathrm{Df}=(\mathrm{r}-1)(\mathrm{c}-1) \mathrm{Df}=$ The degree of freedom

$\mathrm{r}=$ Number of rows $\mathrm{c}=$ Number of columns.

\section{Results and Discussions}

Table 1: Frequencies and Percentage of the Respondents on the basis of their Relationship with their Teachers.

\begin{tabular}{|c|c|c|c|c|}
\hline Statement & Attitude & & & \\
\hline & Yes & No & Uncertain & Total \\
\hline You have positive relationship with all of your teachers & $\begin{array}{c}326 \\
(98.5 \%)\end{array}$ & $\begin{array}{c}5 \\
(1.5 \%)\end{array}$ & & \multirow{12}{*}{$331(100 \%)$} \\
\hline Your relationship with your teachers helps you to motivate you in your education & $\begin{array}{c}320 \\
(96.7 \%)\end{array}$ & $\begin{array}{c}10 \\
(3.0 \%)\end{array}$ & $\begin{array}{c}1 \\
(0.3 \%)\end{array}$ & \\
\hline Your teacher helps you to regulate your behavior & $\begin{array}{c}315 \\
(95.2 \%)\end{array}$ & $\begin{array}{c}10 \\
(3.0 \%)\end{array}$ & $\begin{array}{c}6 \\
(1.8 \%)\end{array}$ & \\
\hline You teacher help you to in your character building & $\begin{array}{c}308 \\
(93.1 \%)\end{array}$ & $\begin{array}{c}9 \\
(2.7 \%)\end{array}$ & $\begin{array}{c}14 \\
(4.2 \%)\end{array}$ & \\
\hline You have any conflict with your teachers & $\begin{array}{c}34 \\
(10.3 \%)\end{array}$ & $\begin{array}{c}291 \\
(87.9 \%)\end{array}$ & $\begin{array}{c}6 \\
(1.8 \%)\end{array}$ & \\
\hline You feel shy or fear while asking question from your teacher & $\begin{array}{c}176 \\
(53.2 \%)\end{array}$ & $\begin{array}{c}132 \\
(39.9 \%)\end{array}$ & $\begin{array}{c}23 \\
(6.9 \%)\end{array}$ & \\
\hline Your relationship with your teacher enables you to discuss your problem with your teacher & $\begin{array}{c}195 \\
(58.9 \%)\end{array}$ & $\begin{array}{c}120 \\
(36.3 \%)\end{array}$ & $\begin{array}{c}16 \\
(4.8 \%)\end{array}$ & \\
\hline Your relationship with your teacher motivates you to take interest in your school work & $\begin{array}{c}262 \\
(79.2 \%)\end{array}$ & $\begin{array}{c}39 \\
(11.8 \%)\end{array}$ & $\begin{array}{c}30 \\
(9.1 \%)\end{array}$ & \\
\hline Your relationship with your teachers helps you in making positive attitude to your school & $\begin{array}{c}259 \\
(78.2 \%)\end{array}$ & $\begin{array}{c}46 \\
(13.9 \%)\end{array}$ & $\begin{array}{c}26 \\
(7.9 \%)\end{array}$ & \\
\hline Your relationship with your teacher helps you to structure your daily experiences & $\begin{array}{c}224 \\
(67.7 \%)\end{array}$ & $\begin{array}{c}46 \\
(13.9 \%)\end{array}$ & $\begin{array}{c}61 \\
(18.4 \%)\end{array}$ & \\
\hline Your relationship teach you in the enabling educational environment & $\begin{array}{c}7 \\
(2.1 \%)\end{array}$ & $\begin{array}{c}237 \\
(71.6 \%)\end{array}$ & $\begin{array}{c}87 \\
(26.3 \%)\end{array}$ & \\
\hline Your relationship with your teachers compels you to discard your studies & $\begin{array}{c}294 \\
(88.8 \%)\end{array}$ & $\begin{array}{c}9 \\
(2.7 \%)\end{array}$ & $\begin{array}{c}28 \\
(8.5 \%)\end{array}$ & \\
\hline
\end{tabular}


Frequencies and percentage distribution of the respondents on the basis of their relationship with their teachers is shown in the Table 1 below. The table shows that nearly all (98.5\%) of the respondents had positive relationship with all of their teachers, only $1.5 \%$ of the respondents said that they do not have positive relationship with their teachers. The result of these matched with Meehan [6], who found that those students will perform well in their education if they have positive relationship with their teachers. It is also clear from the table that $96.7 \%$ of the respondents have said that their relationship with their teachers help them in motivating them in their education, $3.0 \%$ of the respondents said that their relationship with their teachers do not motivate them in their education while $0.3 \%$ of the respondents were uncertain. Teacher student relation had high significance in motivating students towards attainment of educational goals.

These findings show similarity with Teven [7] who said that the student teacher relationship have played an important role in motivation of the students for their learning.

Similarly $95.2 \%$ of the respondents were of the view that their teachers helped them in regulating their behavior, 3.0\% of the respondents said that their teachers do not helped them in regulating their behavior and $1.8 \%$ of the respondents were uncertain. There is a similarity between the result of these findings and Hamre \& Pianta [8] who found that through positive student teacher relationship students learn those behaviors which are socially approved. Moreover, $93.1 \%$ of the respondents said that their teachers helped them in character building, $2.7 \%$ of the respondents said that their teachers do not helped them in their character building and $4.2 \%$ of the respondents were uncertain.

Similarly, $87.9 \%$ of the respondents said that they do not have any conflict with their teachers, $10.3 \%$ of the respondents have conflict with their teachers and $1.8 \%$ of the respondents were uncertain regarding their conflict with their teachers. Strong teacher-students relation as mandatory for regulating student behavior and their character building. These outcomes, however, demands for confidence building measures from the teacher Birch et al. [9]. In addition, 53.2\% of the respondents said that they that they feeling shy of fear while asking question from their teachers, $39.9 \%$ of the respondents said that they do not feel shy or fear while asking question from their teachers and $6.9 \%$ of the respondents were uncertain.

Likewise $58.9 \%$ of the respondents said that their relationship with their teachers enables them to discuss their problems with their teachers, $36.3 \%$ of the respondents said that they are not able to discuss their problems with their teachers and $4.8 \%$ of the respondents were uncertain. In addition $79.2 \%$ of the respondents said that their relationship with their teachers motivates them to take interest in their school work, $11.8 \%$ of the respondents said that they are not motivated to take interest in their studies by the relationship with their teachers and $9.1 \%$ of the respondents were uncertain. An enabling student's teacher relation encourages students to ask questions, share experiences and build interest in their education. These findings are similar to Hamre \& Pianta [8] who found that when there is a positive relationship between student and teacher the students are more likely to take interest in their school work.

Similarly, $78.2 \%$ of the respondents said that their relationship with their teachers helped them in making positive attitude to their school, $13.9 \%$ of the respondents said that their relationship with their teachers do not helped them in making positive attitude toward their school and $7.9 \%$ of the respondents were uncertain. In the same way more than half $67.7 \%$ of the respondents said that they were able to structure their daily experiences with the help of their relationship with their teachers, $13.9 \%$ of the respondent said that their relationship with their teachers do not helped them to structure their daily experiences and $18.4 \%$ of the respondents were uncertain regarding this issue.

In addition $88.9 \%$ of the respondents said their teachers teach them in the good educational environment, $2.7 \%$ of the respondent said that their teachers do not teach them in such environment and $8.5 \%$ of the respondents were uncertain. Similarly $71.6 \%$ of the respondents said that their relationship with teachers do not compelled them to discard their studies, $2.1 \%$ of the respondents said that their relationship with teachers compelled them to discard their studies and $2.1 \%$ of the respondents were uncertain. Student teacher relationship strengthens the educational abilities of students and helps them excel educational achievements. Conversely adverse student teacher relation led to low educational outcomes and dropout Bullock [10] \& Radish [11].

It is concluded from the result that most of the respondents were have positive relationship with their teachers. Their relationship with their teachers motivates them to take interest in their education, regulate their behavior, helped them in their character building and structuring their daily activities.

\section{Association Between Relation with Teacher and Educational Outcomes}

A strong and positive relationship of student and teacher provide the foundation for the healthy development of all children in their school. A positive relationship between student and teacher reduces the risk of school failure and conflict between the teacher and student. The student teacher relation may also foster the socio emotional development of children. Positive student teacher relationship helped the students to develop the sense that they are safe and secure in their school environment and also shaped their social and academic development.

Student teacher relation relationship is also important for those children who are facing early academic and behavioral problems. It is also found that supportive student teacher relationship have played an important role for the diminishing 


\section{Global Journal of Archaeology \& Anthropology}

of aggressive behavior among the children. The need for a positive student teacher do not decrease as children mature but student teacher relationships may be more prominent when students goes from elementary to middle school. Those students who have a conflictual relationship with their teachers, they are not accepted by the rest of the students. Association between relation teacher and educational outcomes is shown in the below Table 2. The table shows that there was a non significant $(\mathrm{P}=0.589)$ association between educational outcomes and positive relationship of children with all of their teachers. Similarly a non significant $(\mathrm{P}=0.116)$ association was found between educational outcomes and relationship of children with their teachers which motivate them in their education. These findings shows similarity with the findings of Wentzel [12] and Neibuhr \& Neibuhr [13] who found that one the most important reason for the association between academic performance and positive teacher student relationship is the motivation and interest of the students for learning.

Table 2: Associations between Relationship with Teacher and Educational outcomes.

\begin{tabular}{|c|c|c|c|c|c|}
\hline Statement & Attitude & \multicolumn{2}{|c|}{ Educational Outcomes } & \multirow{2}{*}{$\begin{array}{c}\text { Total } \\
326(98.5 \%)\end{array}$} & Chi Square $\left(\mathrm{X}^{2}\right)(\mathrm{P}$ \\
\hline \multirow{5}{*}{$\begin{array}{c}\text { You have positive relationship with all of your } \\
\text { teachers }\end{array}$} & \multirow{2}{*}{ Yes } & Yes & No & & \multirow{5}{*}{$X=0.292(P=0.589)$} \\
\hline & & $308(93.1 \%)$ & $18(5.4 \%)$ & & \\
\hline & No & $5(1.5 \%)$ & $0(0.0 \%)$ & $5(1.5 \%)$ & \\
\hline & \multicolumn{4}{|c|}{ Uncertain } & \\
\hline & Total & $313(94.6 \%)$ & $18(5.4 \%)$ & $331(100.0 \%)$ & \\
\hline \multirow{4}{*}{$\begin{array}{l}\text { Your relationship with your teachers helps you } \\
\text { to motivate you in your education }\end{array}$} & Yes & $304(91.8 \%)$ & $16(4.8 \%)$ & $320(96.7 \%)$ & \multirow{4}{*}{$\mathrm{X}=4.301(\mathrm{P}=0.116)$} \\
\hline & No & $8(2.4 \%)$ & $2(0.6 \%)$ & $10(3.0 \%)$ & \\
\hline & Uncertain & $1(0.3 \%)$ & $0(0.0 \%)$ & $1(0.3 \%)$ & \\
\hline & Total & $313(94.6 \%$ & $18(5.4 \%)$ & $331(100 \%)$ & \\
\hline \multirow{4}{*}{ Your teacher helps you to regulate your behavior } & Yes & $300(90.6 \%)$ & $15(4.5 \%)$ & $315(95.2 \%)$ & \multirow{4}{*}{$\mathrm{X}=5.875(\mathrm{P}=0.053)$} \\
\hline & No & $8(2.4 \%)$ & $2(0.6 \%)$ & $10(3.0 \%)$ & \\
\hline & Uncertain & $5(1.5 \%)$ & $1(0.3 \%)$ & $6(1.8 \%)$ & \\
\hline & Total & $313(94.6 \%)$ & $18(5.4 \%)$ & $331(100.0 \%)$ & \\
\hline \multirow{4}{*}{ You teacher help you in your character building } & Yes & $291(87.9 \%)$ & $17(5.1 \%)$ & $308(93.1 \%)$ & \multirow{4}{*}{$\mathrm{X}=0.601(\mathrm{P}=0.741)$} \\
\hline & No & $9(2.7 \%)$ & $0(0.0 \%)$ & $9(2.7 \%)$ & \\
\hline & Uncertain & $13(3.9 \%)$ & $1(0.3 \%)$ & $14(4.2 \%)$ & \\
\hline & Total & $313(94.6 \%)$ & $18(5.4 \%)$ & $331(100.0 \%)$ & \\
\hline \multirow{4}{*}{ You have any conflict with your teachers } & Yes & $31(9.4 \%)$ & $3(0.9 \%)$ & $34(10.3 \%)$ & \multirow{4}{*}{$X=1.148(P=0.563)$} \\
\hline & No & $276(83.4 \%)$ & $15(4.5 \%)$ & $291(87.9 \%)$ & \\
\hline & Uncertain & $6(1.6 \%)$ & $0(0.0 \%)$ & $6(1.8 \%)$ & \\
\hline & Total & $313(94.6 \%)$ & $18(5.4 \%)$ & $331(100.0 \%)$ & \\
\hline \multirow{4}{*}{$\begin{array}{l}\text { You feel shy or fear while asking question from } \\
\text { your teacher }\end{array}$} & Yes & $166(50.2 \%)$ & $10(3.0 \%)$ & $176(53.2 \%)$ & \multirow{4}{*}{$\mathrm{X}=7.899(\mathrm{P}=0.019)$} \\
\hline & No & $128(38.7 \%)$ & $4(1.2 \%)$ & $132(39.9 \%)$ & \\
\hline & Uncertain & $19(5.7 \%)$ & $4(1.2 \%)$ & $23(6.9 \%)$ & \\
\hline & Total & $313(94.6 \%)$ & $18(5.4 \%)$ & $331(100.0 \%)$ & \\
\hline \multirow{4}{*}{$\begin{array}{l}\text { Your relationship with your teacher enables you } \\
\text { to discuss your problem with your teacher }\end{array}$} & Yes & $190(57.4 \%)$ & $5(1.5 \%)$ & $195(58.9 \%)$ & \multirow{4}{*}{$\mathrm{X}=8.009(\mathrm{P}=0.018)$} \\
\hline & No & $108(32.6 \%)$ & $12(3.6 \%)$ & $120(36.3 \%)$ & \\
\hline & Uncertain & $15(4.5 \%)$ & $1(0.3 \%)$ & $16(4.8 \%)$ & \\
\hline & Total & $313(94.6 \%)$ & $18(5.4 \%)$ & $331(100.0 \%)$ & \\
\hline \multirow{4}{*}{$\begin{array}{c}\text { Your relationship with your teacher motivates } \\
\text { you to take interest in your school work }\end{array}$} & Yes & $257(77.6 \%)$ & $5(1.5 \%)$ & $262(79.2 \%)$ & \multirow{4}{*}{$38.517(\mathrm{P}=0.000)$} \\
\hline & No & $29(8.8 \%)$ & $10(3.0 \%)$ & $39(11.8 \%)$ & \\
\hline & Uncertain & $27(8.2 \%)$ & $3(0.9 \%)$ & $30(9.1 \%)$ & \\
\hline & Total & $313(94.6 \%)$ & $18(5.4 \%)$ & $331(100.0 \%)$ & \\
\hline
\end{tabular}




\begin{tabular}{|c|c|c|c|c|c|}
\hline \multirow{4}{*}{$\begin{array}{l}\text { Your relationship with your teachers helps you } \\
\text { in making positive attitude to your school }\end{array}$} & Yes & $256(77.3 \%)$ & $3(0.9 \%)$ & $259(78.2 \%)$ & \multirow{4}{*}{$X=56.077(P=0.000)$} \\
\hline & No & $33(10.0 \%)$ & $13(3.9 \%)$ & $46(13.9 \%)$ & \\
\hline & Uncertain & $24(7.3 \%)$ & $2(0.6 \%)$ & $26(7.9 \%)$ & \\
\hline & Total & $313(94.6 \%)$ & $18(5.4 \%)$ & $331(100.0 \%)$ & \\
\hline \multirow{4}{*}{$\begin{array}{l}\text { Your relationship with your teacher helps you to } \\
\text { structure your daily experiences }\end{array}$} & Yes & $223(67.4 \%)$ & $1(0.3 \%)$ & $224(67.7 \%)$ & \multirow{4}{*}{$\mathrm{X}=38.947(\mathrm{P}=0.000)$} \\
\hline & No & $36(10.9 \%)$ & $10(3.0 \%)$ & $46(13.9 \%)$ & \\
\hline & Uncertain & $54(16.3 \%)$ & $7(2.1 \%)$ & $61(18.4 \%)$ & \\
\hline & Total & $313(94.6 \%)$ & $18(5.4 \%)$ & $331(100.0 \%)$ & \\
\hline \multirow{4}{*}{ Your teacher you in the social environment } & Yes & $285(86.1 \%)$ & $9(2.7 \%)$ & $294(88.8 \%)$ & \multirow{4}{*}{$\mathrm{X}=40.869(\mathrm{P}=0.000)$} \\
\hline & No & $5(1.5 \%)$ & $4(1.2 \%)$ & $9(2.7 \%)$ & \\
\hline & Uncertain & $23(6.9 \%)$ & $5(1.5 \%)$ & $28(8.5 \%)$ & \\
\hline & Total & $313(94.6 \%)$ & $18(5.4 \%)$ & $331(100.0 \%)$ & \\
\hline \multirow{4}{*}{$\begin{array}{l}\text { Your relationship with your teachers compels } \\
\text { you to discard your studies }\end{array}$} & Yes & $7(2.1 \%)$ & $0(0.0 \%)$ & $7(2.1 \%)$ & \multirow{4}{*}{$\mathrm{X}=8.568(\mathrm{P}=0.014)$} \\
\hline & No & $229(69.2 \%)$ & $8(2.4 \%)$ & $237(71.6 \%)$ & \\
\hline & Uncertain & 77 (23.3\%) & $10(3.0 \%)$ & $87(26.3 \%)$ & \\
\hline & Total & $313(94.6$ & $18(5.4 \%)$ & $331(100 \%)$ & \\
\hline
\end{tabular}

The table shows that there was a significant $(\mathrm{P}=0.050)$ association between educational outcomes and teacher helping their students to regulate their behavior which shows that those children whose teachers helped them to regulate their behavior score best in their education Hughes [14]. However, a non significant $(\mathrm{P}=0.741)$ association was found between educational outcomes and teachers helping their children in their character building. In addition students who have any conflict with their teachers was non-significant $(\mathrm{P}=0.563)$ with educational outcomes.

Furthermore, association value of children feeling shy or fear while asking question from their teacher was significant $(\mathrm{P}=0.019)$ with their educational outcomes which shows that those children who do not feel shy or fear in asking question from their teachers score best in their education. Similarly a significant $(\mathrm{P}=0.018)$ association was found between educational outcomes and students relationship with their teachers which enabled them to discuss their problems with their teachers [15]. Similarly association value of educational outcomes and students whose relationship with their teachers enabled them to motivate them to take interest in their school work was highly significant $(\mathrm{P}=0.000)$.

In the same way association value of educational outcomes and children whose relationship with their teachers enabled them in making positive attitude towards their school was also highly significant $(\mathrm{P}=0.000)$. Similarly those students whose relationship with their teachers helped them to structure their daily experiences was highly significant $(\mathrm{P}=0.000)$ with educational outcomes. Likewise, association value of educational outcomes and children whose teacher teached them in the social environment was highly significant $(\mathrm{P}=0.000)$ which makes it clear that those children whom teachers thought them in the social environment score well in their education. Similarly those students whose relationship with their teachers compelled them to discard their studies was significant $(\mathrm{P}=0.014)$ with educational outcomes Meehan [6].

It is concluded from the above result that majority of the children were having positive relationship with all of their teachers which motivated them in their education. Their relationship with their teachers enabled them to discuss their problems with their teachers, motivate them to take interest in their school work and helped them to structure their daily experiences.

\section{Conclusion}

For excellent performance of children in their education, their positive relationship with their teachers played a vital role. Children who had positive, caring relationship with their teachers are likely to be more successful in their education. Those children whose teachers helped them to motivate them in their education, regulate their behavior, helped them in their character building, structure their daily experiences perform well in their educational carrier. Similarly those children who do not feel shy or fear in asking question from their teachers and had any conflict with their teachers were excellent educational outcomes.

\section{Recommendations}

a. Initiating and replicating teacher training programs that ensure improving best educational and psychological skill to teachers so that they can educate students in best efficient way.

b. Strengthening teacher student relationship by reducing reluctance in both groups towards each other and developing strong affiliations among teachers and students based on care 
and sympathy. This will ensure effective utilization of capabilities from both sides for productive output.

\section{References}

1. Wentzel KR, Asher SR (1995) The academic lives of neglected, rejected, popular and controversial children. Child Development 66(3): 754763

2. Kohn A (1999) The schools our children deserve: moving beyond traditional classrooms and tougher standards. Houghton Mifflin, New York, USA.

3. Pianta RC (1999) Enhancing Relationships between Children and Teachers. American Psychological Association.

4. Medina C, Luna G (1999) Teacher as caregiver: making meaning with students with emotional behavioral disabilities. Teacher Development 3(3): 449-465.

5. Hughes JN, Cavell TA, Jackson T (1999) Influence of the teacherstudent relationship on childhood conduct problems: A prospective study. J Clin Child Psychol 28(2): 173-184.

6. Meehan BT, Hughes JN, Cavell TA (2003) Teacher-student relationships as compensatory resources for aggressive children. Child Dev 74(4): $1145-1157$

7. Jason JT, James CMc (1997) The relationship of perceived caring with student learning and teacher evaluation. Communication Education 46(1): 1-9.

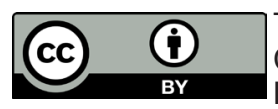

This work is licensed under Creative Commons Attribution 4.0 Licens

DOI: 10.19080/GJAA.2017.02.555576
8. Hamre B, Pianta R (2001) Early teacher-child relationships and the trajectory of children's school outcomes through eighth grade. Child Development 72(2): 625-638.

9. Birch S, Ladd G (1996) Interpersonal relationships in the school environment and children's early school adjustment. In: Wentzel K, Juvonen J (Eds.), Social Motivation: Understanding children's school adjustment. Cambridge University Press, New York, USA, pp. 199-225.

10. Bullock C (2007) The relationship between school building conditions and student achievement at the middle school level in Commonwealth of Virginia, US.

11. Raddysh J (1992) Fading out: comparing high school graduates with high school dropouts. Unpublished master's thesis, Simon Fraser University, Vancouver, British Columbia, Canada.

12. Wentzel K (1998) Social relationships and motivation in middle school: The role of parents, teachers, and peers. Journal of Educational Psychology 90(2): 202-209.

13. Niebuhr K, Neibuhr R (1999) An empirical study of student relationships and academic achievement. Education 119(4): 679.

14. Birch S, Ladd G (1996) Interpersonal relationships in the school environment and children's early school adjustment. In: Wentzel $\mathrm{K}$, Juvonen J (Eds.), Social Motivation: Understanding children's school adjustment. Cambridge University Press, New York, USA, pp. 199-225.

15. Blair C (2002) School readiness: Integrating cognition and emotion in a neurobiological conceptualization of children's functioning at school entry. Am Psychol 57(2): 111-127.

\section{Your next submission with Juniper Publishers will reach you the below assets}

- Quality Editorial service

- Swift Peer Review

- Reprints availability

- E-prints Service

- Manuscript Podcast for convenient understanding

- Global attainment for your research

- Manuscript accessibility in different formats

( Pdf, E-pub, Full Text, Audio)

- Unceasing customer service

Track the below URL for one-step submission https://juniperpublishers.com/online-submission.php 